\title{
Handbook of Florida Water Regulation: Activities in Wetlands and Watersheds ${ }^{1}$
}

\author{
Michael T. Olexa, Luke D'Isernia, Laura Minton, Dulcy Miller, and Sarah Corbett ${ }^{2}$
}

\section{Preface}

This handbook is designed to provide an accurate, current, and authoritative summary of the principle Federal and Florida laws that directly or indirectly relate to agriculture. This handbook should provide a basic overview of the many rights and responsibilities that farmers and farmland owners have under both Federal and Florida laws as well as the appropriate contact information to obtain more detailed information. However, the reader should be aware that because the laws, administrative rulings, and court decisions on which this handbook is based are subject to constant revision, portions of this publication could become outdated at anytime. Several details of cited laws are also left out due to space limitations.

This handbook is distributed with the understanding that the authors are not engaged in rendering legal or other professional advice, and the information contained herein should not be regarded as a substitute for professional advice. This handbook is not all inclusive in providing information to achieve compliance with the Federal and Florida laws and regulations governing water protection. For these reasons, the use of these materials by any person constitutes an agreement to hold harmless the authors, the Florida Cooperative Extension Service, the Institute of Food and Agricultural Sciences, and the University of Florida for any liability claims, damages, or expenses that may be incurred by any person as a result of reference to or reliance on the information contained in this handbook.

\section{Who Regulates Wetlands?}

\section{Army Corps of Engineers}

Federal protection of wetlands stems from several sources. Under the Clean Water Act, the Army Corps of Engineers (ACE) is authorized to issue permits for the discharge of dredge and fill material into waters of the United States. Coupled with this authority, and pursuant to the National Environmental Policies Act (NEPA), the ACE must complete an "environmental impact study" before issuing a permit for work in sensitive areas,

1. This is EDIS document FE606, a publication of the Food and Resource Economics Department, Florida Cooperative Extension Service, Institute of Food and Agricultural Sciences, University of Florida, Gainesville, FL. Published December 2005. Please visit the EDIS website at http://edis.ifas.ufl.edu.

2. Michael T. Olexa, Professor, Food and Resource Economics Department, Florida Cooperative Extension Service, Institute of Food and Agricultural Sciences, University of Florida, Gainesville, FL; Director, Agricultural Law Center, University of Florida, Gainesville, FL; and Chair, Agricultural Law Committee of The Florida Bar. Luke D'Isernia, former student (graduated cum laude in 2005), Levin College of Law, University of Florida, Gainesville, FL. Laura Minton, Attorney, Dean, Mead, Egerton, Bloodworth, Capouano, and Bozarth, Orlando, FL. Dulcy Miller, attorney, Foley and Lardner, LLP, Orlando, FL. Sarah Corbett, Attorney, Florida Second District Court of Appeal, Lakeland, FL.

The Institute of Food and Agricultural Sciences (IFAS) is an Equal Opportunity Institution authorized to provide research, educational information and other services only to individuals and institutions that function with non-discrimination with respect to race, creed, color, religion, age, disability, sex, sexual orientation, marital status, national origin, political opinions or affiliations. U.S. Department of Agriculture, Cooperative Extension Service, University of Florida, IFAS, Florida A. \& M. University Cooperative Extension Program, and Boards of County Commissioners Cooperating. Larry Arrington, Dean 
especially wetlands. As added checks on the ACE's authority to issue dredge and fill permits, the ACE is required to consult with other federal and state agencies whenever relevant and, by virtue of the Clean Water Act, the Administrator of the Environmental Protection Agency (EPA) retains the power to veto ACE-issued permits at the EPA's discretion. While this veto is rarely used, it creates a type of power-sharing system.

\section{Florida Department of Environmental Protection}

On the state level, the Department of Environmental Protection (DEP) is primarily responsible for wetland protection. DEP has been given authority to protect environmentally-sensitive wetland areas and designated areas of critical state concern. More prominent examples include the Florida Keys, Big Cypress Area, Green Swamp Area, the Everglades Protection Area, and the Apalachicola Bay Area.

In addition, the appropriate water management district (WMD) should be consulted with regard to any work to be done near wetlands, whether individually owned or not. The WMDs have adopted MSSW rules that regulate activities in wetlands under DEP supervision. Also, the WMDs are authorized to establish specific permitting criteria for dredge and fill operations in connected and isolated wetlands.

\section{What Is a Wetland?}

For the purpose of ACE permitting, wetlands basically include those areas with a prevalence of vegetation adapted to live in saturated soil conditions. With regard to the DEP's jurisdiction, detailed indexes have been compiled to determine which soil and plant characteristics identify wetlands.

On request, DEP or the appropriate WMD will issue declaratory statements for particular sites regarding whether its jurisdiction extends to that area. They also can issue formal or informal determinations as to the extent of wetlands. These declarations are valid for up to five years as long as physical conditions on the property do not change. The WMDs' definitions of wetlands depend upon the hydrologic, vegetative, and soil characteristics of an area.

\section{When Are Wetland Permits Required?}

Dredge and fill permits are required for any non-exempt activity under Chapter 403, Florida Statutes. The first step in obtaining a permit is assuring the DEP (or WMD) that state water quality standards will not be violated by the proposed dredging and filling activity.

Second, the project cannot be contrary to public interest. Several factors must be considered in this determination, including:

- The effect on public health, safety, welfare, and property rights.

- The effects on fish and wildlife (especially on threatened or endangered species).

- Adverse effects on navigation or harmful erosion.

- A variety of other factors such as effects on marine productivity, temporary or permanent nature of the project, and effects on historical and archaeological resources.

In the final analysis, factors that mitigate destruction of the wetlands are also considered where some damage to the environment is inevitable.

Duration of permits is generally for five years and does not exceed ten years, unless the project cannot reasonably be completed within that time. In these exceptional circumstances, the DEP may issue 25 -year permits. Permitting fees range from $\$ 400$ to $\$ 25,000$ depending upon duration and wetlands that are affected.

\section{What Is Exempt from Wetland Regulations?}

- Federal: In the Federal section, normal farming, silviculture, and ranching activities in wetlands are exempt from the fill permitting mandates of the Clean Water Act. This exemption does not apply to mechanized equipment used in land clearing, as this has been 
held to represent a point source of pollution (i.e., fill).

- Florida: In Florida, generally speaking, agricultural activities and agricultural closed water management systems are exempt from wetland regulation provided that the activities are consistent with agricultural activities. "Agricultural activities" are defined to include all necessary farming and forestry activities that are normal and customary for a particular area provided such operations do not impede or divert the flow of surface waters. "Agricultural closed water management" includes farming or forestry water management systems and farm ponds that are permitted pursuant to Chapter 373, Florida Statutes, or exempted from the permitting requirement of the surface water management statutes (see FE605, Management and Storage of Surface Waters).

\section{What about Mitigation and Mitigation Banking?}

The mitigation and mitigation banking process can apply to wetland activities in the same way as for the management and storage of surface waters (FE605). Mitigation can be used to offset potential harms resulting from activities in wetland areas. The DEP and WMDs have established criteria on when mitigation is appropriate or desirable.

\section{What Is Reclamation?}

Reclamation is the process of returning land that has been mined to a higher dollar value by physically changing the land to a more usable state. Under Florida's land reclamation statute, Chapter 378, Florida Statutes, Section 378.202, land, including wetlands, must be restored to an acceptable condition after a mining operation. Furthermore, reclamation activities must meet the surface and groundwater management requirements of DEP and the appropriate WMD, including design standards for water bodies.

In accordance with these requirements, best management practices (BMP) should be undertaken to minimize erosion. Also, specific procedures for shoreline treatment are prescribed by the BMPs where digging results in the formation of a water body as follows:

- The WMD executive director must be notified of a party's intent to extract minerals, clay, peat, gravel, sand, or other solid substance of commercial value. Usually submission of a conceptual reclamation plan is appropriate.

- All reclamation activities should be conducted in a manner that reduces adverse impacts on surface and groundwater resources, wildlife, and adjacent lands.

An exemption to the notification requirement applies for digging confined to one acre or less in a given year, not to exceed five acres over the life of the mine or the party who extracts. On a similar note, fuller's clay, heavy minerals, limestone, and phosphate are covered separately by permitting requirements.

\section{What about Mangroves?}

The cutting or removing of mangroves is only allowed when authorized by dredge and fill permits. The penalty for unauthorized trimming or alteration of mangroves is the cost of restoration. To avoid such a penalty, permits should be obtained, and a variance exemption may be granted where unique and unnecessary hardship will otherwise result to the applicant. Permits of this type are issued by DEP, the ACE, or a local government holding delegated authority. Cutting or removing is allowed where the environmental impact is minimal. In some cases, selective trimming may be permitted to facilitate enjoyment of riparian rights. In other cases, there are certain exceptions to the permit requirements when dealing with manmade canals, previously planted mangroves, and dead mangroves. Landowners should consult with the DEP or WMD to see if one of these exceptions applies.

Applications to cut or remove mangroves are transferred to county or municipal offices having jurisdiction over the area for which the permit is being requested. Applicants should be aware that there are department-approved dredge and fill regulatory programs to advise applicants on this concern. 


\section{What Are the Penalties?}

Civil liability exists for damage caused to water from unlawful dredging, filling, or destruction of wetlands. Fines may run as high as $\$ 10,000$ per offense, and liability may be joint and several (see FE598, Private Regulation, for discussion of joint and several liability).

Criminal sanctions apply for willful pollution or contamination, making these violations third-degree felonies. Fines up to $\$ 50,000$ per offense and imprisonment for up to five years may be imposed. Furthermore, each day of non-compliance may create a separate violation. Reckless indifference or disregard of the probability of harm to the state's water resources is a second-degree misdemeanor with a fine of not more than $\$ 5,000$ or six months in jail. Failure to obtain a permit, failure to comply with regulations, or making false statements to the permitting authorities are all first-degree misdemeanors punishable by a fine of not more than $\$ 10,000$ or six months in jail.

\section{Source}

Chapter 373, Florida Statutes, Sections 473.413 to 373.403 and 403.9324 to 403.9333

\section{Contact Information}

Wetland and Watershed Management (FE616, Contact Agencies)

- S-1, Florida Water Management Districts

- S-2, Florida Department of Enviromental Protection

- L-1, EPA Region 4 General Information

\section{Acknowledgments}

The authors are indebted to the personnel of both state and federal agencies who provided their time and advice in the preparation of this handbook. The authors are especially indebted to Richard Budell of the Office of Agricultural Water Policy of the Florida Department of Agriculture and Consumer Services for providing funds for the development of this publication. 